\title{
Part 3
}

\section{Special Initiatives across Disciplines}




\title{
Self-education \\ Bridging Secondary and Higher \\ Education - The Importance of Self-regulated Learning
}

\author{
STELLA VOSNIADOU \\ College of Education, Psychology and Social Work, Flinders University, Sturt \\ Road, Bedford Park, SA, 5042, Australia. Email: stella.vosniadou@flinders.edu.au
}

It is proposed that the transition from secondary to higher education can be facilitated by improving secondary school students' capabilities for independent, self-directed, and self-regulated learning (SRL). University learning places high demands on students for complex and independent learning, namely learning that requires the ability to plan, monitor and evaluate one's work and to control one's motivation and emotion. A major stream of educational research has shown the beneficial impact of self-regulated learning on student motivation and has concluded that self-regulation is a significant source of achievement differences among students. However, many secondary school students lack the skills of an independent and self-regulated learner when they enter higher education, something that contributes to considerable student attrition during the first year of university study. In this article I argue that more attention should be paid to the promotion of self-regulated learning in secondary schools. This can be achieved by helping teachers understand how to enrich students' knowledge about learning and strategies to manage it. Some exemplary practices developed at secondary schools are discussed as a means of providing examples of effective learning environments for SRL.

University learning is substantially different from the learning and teaching that takes place in secondary education, making the transition to higher education a challenging process for many students. At university, students are faced with a large and diverse student body, impersonal lecture classes, countless tests and deadlines, and little access to their teachers and tutors for personal guidance and feedback. Often unprepared for the amount of study time expected of them and the increased demand for independent learning and self-reliance, many students decide not to continue their university studies (Gale and Parker 2014; Pascarella and Terenzini 2005). Rausch 
and Hamilton (2006) reported that between 25 and $30 \%$ of the 2.2 million students who started their studies at US universities decided not to continue their studies after the first year. The situation is similar in many universities in Europe and in Australia (Department of Education 2008; EMBO 2006).

There are various ways to bridge the gap between secondary and higher education (Harvey and Knight 1996; Hunt et al. 2002). The proposal discussed in this article centres on the idea of improving students' capabilities for independent, self-directed, and self-regulated learning during the secondary school years. Self-regulated learning (otherwise known as SRL), is a conceptual framework for understanding the cognitive, motivational, and emotional aspects of learning. Although there are different theoretical frameworks from which the self-regulation of learning has been studied, they all agree that learning can be improved and that it is more effective when students can control their motivational states, employ appropriate cognitive and metacognitive strategies, and reflect upon their learning processes and outcomes (Boekaerts 1997; Zimmerman 2002; Winne 2011).

The self-regulation of learning is being increasingly recognized as an important factor when investigating barriers in the transition from secondary to higher education. Universities place high demands on students for complex and independent learning, i.e. learning that requires the ability to plan, monitor and evaluate one's work and to control one's motivation and emotion. These are exactly the capabilities included in the rubric of SRL. Indeed, in a recent review, Bjork et al. $(2013,418)$ argued that 'our complex and rapidly changing world creates a need for self-initiated and self-managed learning ... Knowing how to manage one's own learning activities has become, in short, an important survival tool'. A major stream of educational research, including SRL interventions and meta-analyses, has shown the beneficial impact of self-regulated learning on student motivation and led to the conclusion that self-regulation is a significant source of achievement differences among students (Dignath-van Ewijk and van der Werf 2012; Hattie 2013).

Despite the importance of SRL, many secondary school students do not have adequate knowledge about learning and have not developed the necessary strategies to manage it (Bjork et al. 2013; Lawson and Askell-Williams 2012; Trevors et al. 2016). As a result, they are not ready to face the increased demands for independent learning at university. In a survey of first-year students at an Australian university, about one third of the students stated that they 'feel ill-prepared to choose a university course on leaving school' and that they tend to experience an 'early "reality shock" when their first semester marks begin to come in' (Krause et al. 2005).

Lack of knowledge and skill to manage and control one's learning goes hand in hand with the absence of the explicit promotion of SRL in secondary education. In surveys of college students, about $65 \%$ to $80 \%$ of students answered 'no' to the question 'Do you study the way you do because somebody taught you to study that way?' (Kornell and Bjork 2007; Hartwig and Dunlosky 2012). Teachers seem to recognize the importance of teaching their students how to become self-regulated learners. However, when they are explicitly asked, they say that they do not feel confident to teach SRL or that they do not have the time to do so. In a recent survey of teacher 
practices in Australia, Harding et al. (2017) found that $98.8 \%$ of the participants said that SRL skills are important. However, only $32 \%$ of these teachers reported that they specifically included some elements of SRL when planning a lesson. Of the remaining teachers, $45.8 \%$ said that there is not enough time to teach the content of the curriculum as well as SRL skills, and $24.1 \%$ acknowledged that they did not know how to teach SRL. Studies based on observations of teachers in the classroom, and not on self-reports, demonstrate that there is little or no explicit instruction of SRL in secondary education (e.g. Spruce and Bol 2015).

The lack of emphasis on developing the skills of a competent and independent learner in secondary school is not unrelated to the fact that these skills are not recognized as important and relevant for the transition to higher education by universities. Although students usually undertake difficult background knowledge tests in the disciplines to demonstrate that they have the subject knowledge necessary for their studies, they are not, or are very rarely assessed on whether they possess the skills necessary to manage their learning in an effective way. Establishing such tests at university entrance can be one of the ways to influence secondary schools to engage in actions directed at the development of these skills in their students.

It could be argued that some measures have been taken in this direction, in the context of what is known as the twenty-first century skills movement. Some of the important twenty-first century skills are collaboration, communication, critical thinking, creativity and problem solving. The importance of these skills has usually been emphasized in the context of the transition from school to the workplace, although they are also relevant to the transition from secondary to higher education. Some progress has been made in defining and measuring these skills in the context of the Assessment and Teaching 21st Century Skills (ATC21S) project as well as in the context of the Programme for International Student Assessment (PISA) of the OECD (Griffin et al. 2012; OECD 2003, 2004). Although it could be argued that twenty-first century skills are an important part of the competencies of a self-regulated learner, the SRL project is a larger and more comprehensive approach aiming at the development not only of some isolated skills but also of the learner as a person with knowledge about learning and ability to manage and control his/her cognition and motivation.

\section{Difficulties and Challenges Faced in the Promotion of Self-regulated Learning in Secondary Education}

In thinking about the capabilities of a self-regulated learner, one can distinguish one aspect that concerns 'knowledge about learning' and another that involves 'learning strategies'. Knowledge about learning refers to one's knowledge about how learning happens, about how learning is influenced by motivational orientations, attributions of success and failure, test anxiety and other negative emotions, and about one's personal beliefs about their own learning, including beliefs about self-efficacy, motivations and goals. 'Learning strategies' refers to the repertoire of cognitive, 
metacognitive and motivational strategies that learners can employ to deal effectively with learning tasks. Knowledge about learning and a repertoire of efficient learning strategies are important because knowledge is not something that can be transmitted from teachers to students passively. Human brains are not wax tablets or recording devices. On the contrary, learning depends on what students do to learn - on the actions they use to process the information they receive effectively. Some of these actions include paying attention and encoding information, selecting main ideas, activating relevant prior knowledge and storing it in long-term memory. Efficient learning requires that students constantly monitor incoming information to confirm that it has been understood, comparing it with prior knowledge, elaborating, interrelating and checking for inconsistencies and discrepancies, organising it in memory and storing it, ensuring that it can be easily retrieved and understanding how it applies to other situations (Ambrose et al., 2010; Bransford et al. 1999; Vosniadou 2001).

In an influential study, T.H.M. Chi (and others) investigated how undergraduate students who had not taken any prior physics courses learned to solve problems in mechanics (Chi et al. 1989). The students studied worked-out examples of mechanics problems and were then evaluated on how they solved a set of new problems. Although the students did not differ in their prior knowledge of physics, some of the students showed greater success at solving the new problems than others. The results revealed marked differences between the 'good' and 'poor' students in the way they studied the worked-out examples. One important difference was that the good students were much better in realising when they failed to understand something and what it was that they failed to understand, compared with the poor students. The poor students generated an average of only 1.1 statements indicating failure to comprehend, while the good students generated an average of 9.3 such statements. Another crucial difference was that the good students were able to identify the loci of their misunderstandings and raise specific questions whereas the poor students stated their lack of understanding in general terms. The specific questions raised by the good students were much more likely to be related to critical physics principles and concepts compared with the general questions raised by the poor students. Third, the good students were able to start an inferential process to generate answers to these specific questions by producing self-explanations, which made their understanding of the physics principles described in the text more complete. Indeed, the good students produced a significantly greater number of such self-explanations compared with the poor students.

The results of this research (Chi et al. 1989) show that student learning depends critically on the way students monitor their comprehension while they study: how well they can detect failures to understand and how well they employ appropriate learning strategies to bridge new information with what they already know in order to form a meaningful and cohesive knowledge schema. Comprehension monitoring and evaluation strategies are important for learning in all disciplines but especially important in science and mathematics. Learning in these areas often requires understanding difficult, complex and counter-intuitive theories, which necessitate 
considerable re-organisation of existing concepts, the creation of new models and representations and other conceptual changes (Vosniadou 2013; Chi 2008). Although present in secondary school, these learning challenges greatly multiply upon entering higher education, making SRL knowledge and strategies even more necessary. Secondary school teachers can play a critical role in helping their students acquire the SRL knowledge and strategies that can help them succeed at university.

Teaching the skills of an independent learner is not an easy matter. It requires substantial changes in the traditional way of teaching, which is focused primarily on the provision of subject matter content. For one thing it requires giving students more independence and control over their learning, something that teachers are often reluctant to do. Keeping control of the classroom is important for many teachers who do not know how to manage a more open and student-centred learning environment. The promotion of self-regulated learning also requires taking a different approach to teaching subject content itself. Rather than focusing on the transmission of content information, it requires that teachers design constructive and interactive tasks that students can use to process content information critically. It also requires teaching students the strategies needed for the successful completion of such tasks. Teachers who believe that their role in the classroom is the provision of subject content may find it difficult to agree with the proposition of SRL that learning depends on what students do to learn and that teachers can best help their students by influencing their knowledge about learning and the strategies they use to learn (Battista 1994; Calderhead 1996; Lane 2015; Perry et al. 2015; Torff and Sternberg 2001).

Another roadblock to teaching SRL is the belief of some teachers (and many students) that learning cannot be taught and improved (Vosniadou et al. 2017). Interpreting individual differences in learning to mean that some students are born smart and learn quickly and effortlessly while others are not, some teachers (and students) conclude that it is not very helpful to teach people how to learn. This conclusion is not consistent with the research evidence showing that when students are taught SRL strategies their learning improves. Even when teachers believe that learning can be improved, research shows that they may still not be fully persuaded that acquiring the skills of a self-regulated learner will have an important impact on student achievement (Vosniadou et al. 2017; Vosniadou et al. 2020).

\section{Secondary School Programmes That Can Help Students Prepare for University Learning}

Some secondary schools have succeeded in developing exemplary educational practices to foster SRL skills in students. One of these schools is the Australian Science and Mathematics School (ASMS). ASMS was established in 2003 out of a joint project between Flinders University and the SA (South Australia) Government Department for Education. The vision was to provide a State school, built on university grounds, with a focus on science and mathematics. The school now serves as a state-wide focal point for professional learning and research aimed at fostering 
improvement, innovation and reform in Science and Mathematics education and in self-directed learning. It offers a novel, interdisciplinary, student-centred curriculum for years 10-12 in science and mathematics. ASMS has developed a new understanding of the transition from secondary to tertiary education, by creating a learning environment which, like a university learning environment, demands a great deal of independent learning, but which also offers a lot of support and guidance to students to learn how to be independent learners. This is done through the school's Learning Studies Programme.

The Learning Studies Programme is designed to help students become aware of themselves as learners by developing their knowledge about learning and the strategies needed to manage and control their learning. The emphasis is to support the students to become independent learners in order to do well at ASMS but also in order to make a successful transition to tertiary education and plan their life beyond ASMS. The programme consists of three elements: The Learning Studies Group, the Personalised Learning Plan and the Learning Conversations. The Learning Studies Group consists of eight students and a teacher and meets every day for 40 minutes. It is formed when students start attending ASMS and continues until they graduate (years 10-12). The purpose of the Learning Studies Group is to help students understand themselves as learners. During group meetings the students discuss the subjects they are doing, the difficulties they are facing, and articulate and revise their goals. The teacher provides information relevant to knowledge about learning and learning strategies, such as time management, goal setting, and positive mindset. The Personalised Learning Plan involves the development of a personal profile of achievement related to the ASMS capabilities, which the students need to document in an e-portfolio. The learning teacher supports students to develop their Personal Learning Plan by helping them to discuss their goals, understand which goals they have accomplished, which goals they need to work on, and which goals they need to revise. Learning Conversations are compulsory student/parent meetings that take place twice each year. Instead of traditional parent-teacher conferences, the students have an opportunity to present to their parents an e-portfolio with examples of the work they did during the year. This is a time for students to reflect on their learning journey and share it with their parents - to show their parents the work they did during the year and talk to them about their goals.

A group of educators at Flinders University in recent collaborations with the University of Melbourne supported by grants from the Australian Research Council have developed programmes to further develop some of the ASMS practices and create programmes that promote self-directed and self-regulated learning that can be easily implemented in more traditional schools (Vosniadou et al. 2017). One element of these programmes is for schools to offer a course on learning to their students. This course includes information about how learning happens in the brain, as well as about how one's motivations, emotions and beliefs can influence learning and academic performance. Another element of these programmes is to help teachers understand the impact of their actions and their talk on student learning and achievement. Examples are offered and discussed of learning environments that give the 
opportunity to students to engage in independent or collaborative constructive learning, coupled with explicit and implicit strategy instruction and metacognitive support for the development of students' awareness of themselves as learners. This metacognitive support can come from the teacher's frequent reference to aspects about learning or characteristics of learners that might be relevant during a lesson. For example, the students can be reminded to draw on their knowledge about how to study for an exam, what to do to obtain teacher feedback, how to plan a project, how to monitor and evaluate their learning, or how to control their emotions and anxiety. Preliminary evidence indicates that such programmes can be very effective in helping teachers create learning environments that promote self-regulated learning.

\section{Concluding Remarks}

There are different proposals about how to bridge the transition between secondary and tertiary education. In this paper we offered some ideas about programmes that can be implemented at the secondary school level to prepare students for university learning. These programmes require that educators give less emphasis to the provision of subject content and more emphasis on helping students acquire the skills and strategies needed to understand content critically, i.e. to create independent learners. Independent learners are problem solvers who can locate the relevant information to solve a problem and can draw the inferences necessary to create new knowledge and apply it to new situations. In order to promote independent and effective learning, teachers must understand that student academic performance depends on what students do to learn and that what students do to learn depends critically on teachers' actions and talk in the classroom.

\section{References}

Ambrose SA, Bridges MW, DiPietro M, Lovett MC and Norman MK (2010) How Learning Works: Seven Research-based Principles for Smart Teaching. San Francisco: Jossey-Bass.

Battista MT (1994) Teacher beliefs and the reform movement in mathematics education. Phi Delta Kappan 75, 462-470.

Bjork RA, Dunlosky J and Kornell N (2013) Self-regulated learning: beliefs, techniques, and illusions. Annual Review of Psychology 64, 417-444. doi.org/10.1146/ annurev-psych-113011-143823.

Boekaerts M (1997) Self-regulated learning: a new concept embraced by researchers, policy makers, educators, teachers, and students. Learning and Instruction 7, 161-186. https://doi.org/10.1016/S0959-4752(96)00015-1.

Bransford JD, Brown AOL and Cockling RR (eds) (1999) How People Learn: Brain, Mind, Experience, and School. Washington, DC: National Academy Press.

Calderhead J (1996) Teachers: beliefs and knowledge. In Berliner DC and Calfee RC (eds), Handbook of Educational Psychology. New York: Macmillan, pp. 709-725.

Chi MTH (2008) Three types of conceptual change: Belief revision, mental model transformation, and categorical shift. In Vosniadou S (ed.), Handbook of Research on Conceptual Change. Hillsdale, NJ: Erlbaum, pp. 61-82. 
Chi MTH, Bassok M, Lewis MW, Reimann P and Glaser R (1989) Self-explanations: how students study and use examples in learning to solve problems. Cognitive Science 13(2), 145-182.

Department of Education, Employment and Workplace Relations (2008) Students 2007: selected higher education statistics. Available at http://www.dest.gov.au/sectors/ higher_education/publications_resources/profiles/Students_2007_full_year_. htm (accessed 25 March 2020).

EMBO (2006) From school to university—a report on the transition from secondary school biology education to university in Europe. Available at http://www.embo. org/scisoc/report.pdf (accessed 15 March 2020).

Dignath-van Ewijk C and van der Werf G (2012) What teachers think about selfregulated learning: investigating teacher beliefs and teacher behavior of enhancing students' self-regulation. Education Research International, Volume 2012. doi.org/ 10.1155/2012/741713.

Gale T and Parker S (2014) Navigating change: a typology of student transition in higher education. Studies in Higher Education 39(5), 734-753. doi:10.1080/ 03075079.2012.721351.

Griffin P, McGaw B and Care E (eds) (2012) Assessment and Teaching of 21st Century Skills. Dordrecht: Springer.

Harding SM, Nibali N, Griffin P, Graham L and English N (2017) Teaching Selfregulated Learning in Victorian Classrooms. Paper presented at the Australian Association for Research in Education (AARE) conference as part of a symposium: Beliefs and Knowledge about Learning and Teaching in Teachers and Students, Melbourne, Victoria, Australia.

Hartwig MK and Dunlosky J (2012) Study strategies of college students: are self-testing and scheduling related to achievement? Psychonomic Bulletin \& Review 19, $126-134$.

Harvey L and Knight, PT (1996) Transforming Higher Education. Buckingham: Open University Press.

Hattie J (2013) Visible Learning: A Synthesis of Over 800 Meta-analyses Relating to Achievement. London: Routledge.

Hunt L, Kershaw $\mathbf{L}$ and Seddon $\mathbf{J}$ (2002) Authentic transitions: the click around ECU on-line transition to university program. Higher Education Research \& Development 25, 338-353.

Kornell N and Bjork RA (2007) The promise and perils of self-regulated study. Psychonomic Bulletin \& Review 14, 219-224.

Krause K-L, Hartley R, James R and McInnis C (2005) The First-year Experience in Australian Universities: Findings from a Decade of National Studies. Australia: Department of Education, Science and Training, p. 115.

Lane R (2015) Experienced geography teachers' PCK of students' ideas and beliefs about learning and teaching. International Research in Geographical \& Environmental Education, 24(1), 43-57. https://doi.org/10.1080/10382046.2014. 967113.

Lawson MJ and Askell-Williams H (2012) Framing the features of good quality knowledge for teachers and students. In Kirby JR and Lawson MJ (eds), Enhancing the Quality of Learning. New York: Cambridge University Press, pp. $137-159$.

OECD (2003) The Definition and Selection of Competencies (DeSeCo): Executive Summary of the Final Report. Paris: OECD.

OECD (2004) Problem Solving for Tomorrow's World. First Measures of Cross Curricular Competencies from PISA 2003. Paris: OECD. 
Pascarella ET and Terenzini PI (2005) How College Affects Students. A Third Decade of Research, vol. 2. San-Francisco: Jossey-Bass.

Perry NE, Brenner CA and MacPherson N (2015) Using teacher learning teams as a framework for bridging theory and practice in self-regulated learning. In Cleary TJ (ed.), Self-regulated Learning Interventions with At-risk Youth. Washington, DC: American Psychological Association, pp. 229-250.

Rausch JL and Hamilton MW (2006) Goals and distractions: explanations of early attrition from traditional university freshmen. The Qualitative Report 11, 317-334.

Spruce R and Bol L (2015) Teacher beliefs, knowledge, and practice of self-regulated learning. Metacognition and Learning 10, 245-277. https://doi.org/10.1007/ s11409-014-9124-0.

Torff B and Sternberg RJ (2001) Intuitive conceptions among learners and teachers. In Torff B and Sternberg RJ (eds), Understanding and Teaching the Intuitive Mind: Student and Teacher Learning. Mahwah, NJ: Erlbaum.

Trevors G, Feyzi-Behnagh R, Azevedo R and Bouchet F (2016) Self-regulated learning processes vary as a function of epistemic beliefs and contexts: mixed method evidence from eye tracking and concurrent and retrospective reports. Learning and Instruction 42, 31-46. https://doi.org/10.1016/j.learninstruc.2015.11.003.

Vosniadou S (2001) How Children Learn. Educational Practices Series 7, International Academy of Education and International Bureau of Education, UNESCO, (www.ibe.unesco.org/publications).

Vosniadou S (2013) International Handbook of Research on Conceptual Change (2nd edn). London: Routledge.

Vosniadou S, Pobke K, Heath J, Van Deur P and Jeffries D (2017) Fostering the Development of Self-directed Learners. Paper presented at the annual conference of the Australian Association for Research in Education, Canberra, Australia (in press).

Vosniadou S, Lawson M, Wyatt M, Van Deur P, Jeffries D \& Igusti D (2020) Preservice teachers' beliefs regarding the importance of teaching students learning strategies: a conceptual change approach. International Journal of Educational Research (in press).

Winne PH (2011) A cognitive and metacognitive analysis of self-regulated learning. In Zimmerman BJ and Schunk DH (eds), Handbook of Self-regulation of Learning and Performance. New York: Routledge, pp. 15-32.

Zimmerman BJ (2002) Becoming a self-regulated learner: an overview. Theory into Practice 41, 64-70.

\section{About the Author}

Stella Vosniadou is currently Strategic Professor in the College of Education, Psychology and Social Work at Flinders University, Australia, after having served for many years as Professor of Cognitive Psychology in the Department of Philosophy and History of Science at the National and Kapodistrian University of Athens, Greece (1995-2013). She is a fellow of Academia Europaea, of the International Academy of Education, of the American Association for Educational Research (AERA), and of the Cognitive Science Society, and has served as a President of the European Association for Research on Learning and Instruction (1995-1997) and chair of the Cognitive Science Society (2012-2013). Her research is 
in the area of learning and cognitive development with a focus on how students understand counterintuitive concepts in science and mathematics. She is well known for her work on conceptual change, for which she received the 2011 Distinguished International Contributions to Child Development Award by the Society for Research in Child Development. Her most recent research investigates teacher cognition, the design of student-centred learning environments for the teaching of science and mathematics, and the promotion of self-regulated learning. She is the recipient of numerous grants from the Australian Research Council, the European Commission and the US National Science Foundation, the author or co-author of more than 150 publications, including a number of authored and edited books, with over 20,000 citations. She served as Editor, Associate Editor, and Editorial Board Member of top national or international journals, such as Learning and Instruction, Mathematical Thinking and Learning, Journal of Cognitive Science, Educational Psychologist, and is currently the editor of the Educational Practices Series, a publication of the International Bureau of Education of the UNESCO and International Academy of Education. 